\title{
Impact of production parameters on physiochemical characteristics of wood ash for possible utilisation in cement-based materials
}

Sigvardsen, Nina M.; Kirkelund, Gunvor M.; Jensen, Pernille E.; Geiker, Mette R.; Ottosen, Lisbeth M.

Published in:

Resources, Conservation and Recycling

Link to article, DOI:

10.1016/j.resconrec.2019.02.034

Publication date:

2019

Document Version

Peer reviewed version

Link back to DTU Orbit

Citation (APA):

Sigvardsen, N. M., Kirkelund, G. M., Jensen, P. E., Geiker, M. R., \& Ottosen, L. M. (2019). Impact of production parameters on physiochemical characteristics of wood ash for possible utilisation in cement-based materials. Resources, Conservation and Recycling, 145, 230-240. https://doi.org/10.1016/j.resconrec.2019.02.034

\section{General rights}

Copyright and moral rights for the publications made accessible in the public portal are retained by the authors and/or other copyright owners and it is a condition of accessing publications that users recognise and abide by the legal requirements associated with these rights.

- Users may download and print one copy of any publication from the public portal for the purpose of private study or research.

- You may not further distribute the material or use it for any profit-making activity or commercial gain

- You may freely distribute the URL identifying the publication in the public portal 


\section{Impact of Production Parameters on}

\section{Physiochemical Characteristics of Wood Ash for 3 Possible Utilisation in Cement-based Materials}

4 Nina M. Sigvardsen ${ }^{\mathrm{a}, *}$, Gunvor M. Kirkelund ${ }^{\mathrm{a}}$, Pernille E. Jensen ${ }^{\mathrm{a}}$, Mette R.

5 Geiker $^{\mathrm{b}}$, Lisbeth M. Ottosen ${ }^{\mathrm{a}}$

$6 \quad{ }^{a}$ Department of Civil Engineering, Technical University of Denmark, Kgs. Lyngby, Denmark

$7 \quad{ }^{b}$ Department of Structural Engineering, Norwegian University of Science and Technology, Trondheim, Norway

8 Abstract

9 Energy production is reorganised to mitigate the pressure on the global environment. This 10 reorganisation leads to an increase in the production of wood ash (WA). Multivariate modelling 11 was used to identify the link between production parameters and the physicochemical 12 characteristics of different WAs and to determine which production parameters result in the WAs 13 most suitable for utilisation in cement-based materials. Based on the multivariate model partial 14 least square, WA originating from circulating fluidised bed combustion of wood chips made 15 from whole trees is the optimal type of WA when utilised as a supplementary cementing material with pozzolanic activity. WA originating from the combustion of wood chips made from whole trees is the optimal type of WA when utilised as a supplementary cementing material with hydraulic activity. Furthermore, the combustion method and type of ash were seen to have the largest influence on the physiochemical characteristics of WAs compared to the other production parameters included in this study.

Keywords: wood ash, supplementary cementitious material, multivariate modelling

\section{Introduction}

The pressure on the global environment has led to an increase in the demand for renewable energy. In April 2017, 26 of the 28 EU nations, stated they would not invest in new coal-fired power plants after 2020, in close accordance to the Paris Agreement and the goal to provide

\footnotetext{
${ }^{*}$ Corresponding author.

E-mail address: nimasi@byg.dtu.dk (N.M. Sigvardsen).
} 
$100 \%$ carbon neutral fuel by 2050 (Neslen, 2017). The agreement also includes a demand to reorganise the existing energy sector. Since coal combustion plants already exist, a prevalent option is to transform the existing plants to use alternative, sustainable fuels. One abundant fuel is biomass, defined as an organic material, e.g. plant material such as wood, straw and bagasse (McKendry, 2002).

\subsection{Utilisation of WA}

Incineration of different types of wood products, e.g. wood pellets or chips, for energy production causes a significant increase in the production of wood ash (WA). 48,000 tonnes WA is produced annually in Denmark (Emineral A/S, 2019). A major portion of the produced WA is land-filled and thus not utilised (Etiégni and Campbell, 1991), which could lead to a range of potential problems. WA consists of fine particulate matter, which is easily airborne by winds. Thus landfilling of WA can be a potential health risk to nearby residents or a source of pollution of the surrounding nature (Cheah and Ramli, 2011a). Further, landfilling of WA can lead to leaching of chemical elements from the WA and thus contamination of the groundwater (Udoeyo et al., 2006). To avoid contamination a properly engineered landfill is required, making landfilling of WA uneconomical (Cheah and Ramli, 2011a). Thus, utilisation of WA is of interest as an alternative to landfilling.

Application of WA in cement-based materials as a supplementary cementitious material (SCM) or filler has been studied in the literature (Berra et al., 2015; Chowdhury et al., 2015; Elinwa and Mahmood, 2002; Rajamma et al., 2009a; Ramos et al., 2013; Siddique, 2012; Udoeyo et al., 2006). The findings of these studies (Berra et al., 2015; Chowdhury et al., 2015; Elinwa and Mahmood, 2002; Rajamma et al., 2009a; Ramos et al., 2013; Siddique, 2012; Udoeyo et al., 2006) vary markedly e.g. in regards to the obtained compressive strength for mortar samples containing WA. Udoeyo et al., (2006), Berra et al., (2015), and Elinwa and Mahmood, (2002) all concluded a decrease in the compressive strength when using WA as a partial cement replacement. Rajamma et al., (2009a) saw no decrease in the compressive strength for a $10 \%$ replacement of cement with WA and Siddique, (2012), Ramos et al., (2013), and Chowdhury et al., (2015) all concluded an initial decrease in the compressive strength, but an increase in the compressive strength over time due to pozzolanic activity. These different results are depending on which type of WA is used. WA physiochemical characteristics vary depending both on the wood products, e.g. wood chips or pellet, and on the combustion process, e.g. temperature, and technology (Cheah and Ramli, 2011a; Siddique, 2008). 
Utilisation of WA in cement-based materials is not approved according to EN 450-1, (2012), which is the current European standard for utilisation of fly ashes as mineral admixtures in cement-based materials. Nevertheless, EN 450-1, (2012) will be used as a reference for evaluation of the WAs in this work, as in several previous studies (Berra et al., 2015; Rajamma et al., 2009a; Ramos et al., 2013).

\subsection{Environmental perspectives on utilisation of WA in cement-based materials}

About $5 \%$ of the global $\mathrm{CO}_{2}$-emission originates from the production of Portland cement (International Energy Agency (IEA), 2007). Utilisation of WA as a partial cement replacement could potentially contribute to a reduction of the global $\mathrm{CO}_{2}$-emission and conserve raw materials (Schneider et al., 2011; Teixeira et al., 2016). Utilisation of WA as a partial filler replacement could also conserve raw materials.

Teixeira et al., (2016) conducted a life cycle assessment comparing the potential environmental impact from cradle-to-gate of $1 \mathrm{~m}^{3}$ of concrete with Portland cement and 0, 20, 40 and $60 \%$ substitutions of cement with different types of by-products (coal fly ash, biomass fly ash, and co-combusted coal and biomass fly ash). They studied cradle-to-gate, as the use and disposal of concrete were assumed to result in the same environmental impacts regardless the type of concrete. Teixeira et al., (2016) included six environmental impact categories: global warming, ozone layer depletion, acidification potential, eutrophication potential, formation potential of tropospheric ozone and abiotic depletion potential of fossil resources. In general, the incorporation of fly ash, regardless of type, reduced the environmental impacts, primarily due to the decrease in the cement consumption, thus the $\mathrm{CO}_{2}$-emission. They showed that the biomass fly ash had the best environmental performance, increasing with replacement rate.

The life cycle assessment presented by Teixeira et al., (2016) only takes into account environmental impacts and does not take into account the mechanical performance of concretes with biomass fly ash, both parameters that could limit the use. Further, the requirements for binders in cement-based materials, according to EN 450-1, (2012) are comprehensive and conservative. These requrements ensures the necessary durability of a concrete structure, which is another important aspect, not taken into account in the life cycle assessment (Teixeira et al., 2016).

The environmental performance of concrete with WA highly encourages utilisation of biomass fly ash in concrete; however, further studies are required, regarding, e.g. mechanical response, 
durability, reactivity of WA, influence of WA on the hydration phases and possibilities and influence of pre-treatment of WA, in order to utilise biomass fly ashes in cement-based materials.

\subsection{Multivariate modelling}

The use of multivariate statistical methods has been applied for several purposes in the literature, e.g. by Pedersen et al., (2015) for evaluation of the efficiency of electrodialytic removal of heavy metals from polluted harbour sediments and by Christensen et al., (2005) for evaluation of biodegradation of mineral oil. Voshell et al., (2018) used multivariate statistical methods to get a better understanding of the origin of the trance elements $\mathrm{As}, \mathrm{Cd}, \mathrm{Cr}, \mathrm{Cu}, \mathrm{Ni}$. $\mathrm{Pb}, \mathrm{Zn}, \mathrm{K}, \mathrm{Mg}, \mathrm{Ca}$, and $\mathrm{Al}$ in biomass ashes.

This work identifies the link between production parameters and the physicochemical characteristics of WA by the use of multivariate statistical analysis. The production parameters were selected by the authors and cover both material and process parameters (see table 1.). The optimal production parameters for WA to be applicable in cement-based materials were identified based on the assumption that requirements described in EN 450-1, (2012) and EN 197-1, (2011) are valid for WA. The production parameters used in this work for multivariate statistical analysis is; the initial water content (of the biofuel), the mean combustion temperature, type of biofuel (wood chips, wood pellets or wood chips and powder), origin of biofuel (whole trees (including logs, bark, buds and pine needles) or logs), and combustion method (circulating fluidized bed (CFB) or grate combustion). The production parameters were supplied by the individual biomass combustion facility. The type of ash is further included as a production parameter (bottom (B), mixed (M) or fly ash (F)). The authors selected these production parameters, based on knowledge available at the individual biomass combustion facility. However, the inclusion of more production parameters, if possible, would result in a more detailed model.

\section{Materials and methods}

\subsection{Investigated WAs}

Eleven different types of WA were used in this study, nine different wood ashes from five different biomass combustions facilities in Denmark and two different wood ashes from one biomass combustion facility in Sweden. An overview of the eleven WAs and their production 
parameters can be found in table 1. Collectively, the eleven WAs used in this study will be referred to as the investigated ashes.

The WAs were sampled from end of March to the beginning of April 2017, except WMFA2, which was collected at the beginning of July 2017. The individual biomass combustion facilities supplied samples of the ashes from deposit storage. All ashes were subsequently stored in closed plastic buckets protected from heat and light sources. The plastic bucket was mixed before sample collection from the bucket in order to ensure a representative ash sample.

\subsection{Characterisation methods}

Characterisation was made on dried WA $\left(105^{\circ} \mathrm{C}, 24\right.$ hours $)$ in order to assure sample without free water. Scanning Electron Microscope (SEM) was used to analyse the morphology. The content of minerals was analysed by X-ray diffractometry (XRD) measured with a PanAnalytical X-ray diffractometer, sat at the PW3064 Spinner stage, with $\mathrm{Cu}-\mathrm{K} \alpha$ radiation measuring between $4^{\circ} 2 \theta$ and $1005^{\circ} 2 \theta$ with a step size of $0.002^{\circ} 2 \theta$ and a sampling time per step of 24.8 s. The XRD plots were qualitatively evaluated using X'Pert HighScore Plus software, with data from the International Centre for Diffraction Data (ICDD). The chemical composition of the investigated WAs was determined by X-ray fluorescence (XRF). The particle size distribution and specific surface area were determined by laser diffraction using a Mastersizer 2000 instrument. The $\mathrm{pH}$ and conductivity of the WAs were measured in a 1:2.5 solid to liquid ratio suspension in distilled water with the respective electrodes after 1-hour of stirring with a magnetic stirrer. The suspension was filtered followed by measurement of $\mathrm{Cl}^{-}$ and $\mathrm{SO}_{4}{ }^{2-}$ concentrations by Ion Chromatography. Loss on ignition (LoI) was measured in accordance with CEN (European Committee for Standardization), (2009), i.e. at $550{ }^{\circ} \mathrm{C}$ and EN 196-2, (2005), i.e. at $950{ }^{\circ} \mathrm{C}$. The solubility in water was determined: ash and distilled water were mixed to an L/S (liquid-to-solid) ratio 5 and shaken for $1 \mathrm{~min}$. After settling, the water was decanted. This procedure was repeated three times (Kirkelund et al., 2016). Finally, the suspension was filtered and the ash dried and weighed. The carbonate volume was determined by reaction with hydrochloric acid measured by the use of Schreiber equipment (Hamid, 2009). All tests conducted for the characterisation of the WAs were repeated three times, except the XRF analysis. A ternary diagram was plotted for the components $\mathrm{CaO}, \mathrm{SiO}_{2}$ and $\mathrm{Al}_{2} \mathrm{O}_{3}$. All excess components were subtracted from the total bulk composition before plotting. Thus the ternary diagram displays the relationship between the relative quantities of 
the three components. SIMCA 14.1 Software is used for conducting the multivariate statistical analysis.

\section{Results and discussion}

\subsection{Physiochemical characteristics of WA}

The possibility of using the investigated WAs in cement-based materials has been evaluated based on the physiochemical characteristics measured for the investigated WAs. The characterisation comprises physicochemical characteristics (tables 2 and 3), percentage complying with the filler limit and compliance with category $\mathrm{N}$ (table 2), mineralogical composition (table 2 and figure 3 ) and morphology (figure 4).

\subsubsection{Pozzolanic activity}

Pozzolanic activity is facilitated by a high amount of $\mathrm{SiO}_{2}, \mathrm{Al}_{2} \mathrm{O}_{3}$ and $\mathrm{Fe}_{2} \mathrm{O}_{3}$, referred to as primary oxides, and according to (EN 450, 2012) the $\sum$ primary oxides $>70 \%$ for a pozzolan. A pozzolan has, in itself, little or no cementitious value but will, in the presence of moisture, react with calcium hydroxide and form compounds possessing cementitious properties (ASTM International C125-15a, 2003).

Pozzolanic activity was reported for WAs in several studies (Chowdhury et al., 2015; Elinwa and Mahmood, 2002; Ramos et al., 2013; S. V. Vassilev et al., 2010), concluded due to a content of primary oxides above $70 \%$ (EN 450, 2012). None of the investigated WAs in this study complies with this limit. The highest content of primary oxides was found for WCBA with a content of primary oxides of $64 \%$. The rest of the WAs had at a content $\leq 25 \%$. The primary oxides for the WAs in this study are in the following order $\mathrm{SiO}_{2}>\mathrm{Al}_{2} \mathrm{O}_{3}>\mathrm{Fe}_{2} \mathrm{O}_{3}$ for bottom and mixed ashes, except for WPMA, and $\mathrm{SiO}_{2}>\mathrm{Fe}_{2} \mathrm{O}_{3}>\mathrm{Al}_{2} \mathrm{O}_{3}$ for fly ashes, except for WCFA3. The WA originating from CFB combustion (WCBA and WCFA3) arrived at the highest amount of primary oxides, mainly due to a high content of $\mathrm{SiO}_{2}$. A high content of $\mathrm{SiO}_{2}$ is due to sand particles, which make the suspension bed, and which are carried with the flue gas during combustion with the CFB technology (van Loo and Koppejan, 2010). Sand is considered inert (Wig, 1913), thus a part of the $\mathrm{SiO}_{2}$ content in WCBA and WCFA3 could be inert bed sand. 
179 The content of primary oxides was above $70 \%$ in the WAs in Chowdhury et al., (2015), Elinwa

180 and Mahmood, (2002), Ramos et al., (2013) and S. V. Vassilev et al., (2010) and in the order

$181 \mathrm{SiO}_{2}>\mathrm{Fe}_{2} \mathrm{O}_{3}>\mathrm{Al}_{2} \mathrm{O}_{3}$, an order which corresponds to the findings in this study. Rajamma et 182 al., (2009a) investigated a WA originating from a biomass thermal power plant using forest 183 residues as fuel. The content of primary oxides was $52 \%\left(\mathrm{SiO}_{2}=41 \%, \mathrm{Al}_{2} \mathrm{O}_{3}=9 \%, \mathrm{Fe}_{2} \mathrm{O}_{3}=\right.$ $1843 \%$ ), but still argued to contribute to the pozzolanic activity, due to the $\mathrm{CaO}$ and $\mathrm{OH}^{-}$ 185 concentrations based on a direct pozzolanic activity test showing a saturation curve well below 186 that of cement, which indicates pozzolanic activity of the WA (Rajamma et al., 2009a). The 187 oxides of the WA investigated by Rajamma et al., (2009a) was similar to WCBA investigated 188 in this study. Thus, WCBA might similarly show pozzolanic behaviour, even though it contains 189 only $64 \%$ primary oxides. The remaining WAs of this study are considered to have very little 190 or no pozzolanic activity, due to the low amount of primary oxides $(<25 \%)$.

\subsubsection{Hydraulic activity}

Hydraulic activity describes the ability of a material to set and harden, while submerged in water, by forming cementitious products in a hydration reaction (Snellings et al., 2012). Hydraulic activity is governed by the content of $\mathrm{SiO}_{2}$ and $\mathrm{CaO}$ (EN 197-1, 2011) and

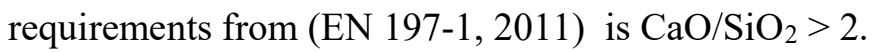

Hydraulic activity for WAs was investigated in Berra et al., (2015), Cheah and Ramli, (2011b), and Rajamma et al., (2009a). Berra et al., (2015) investigated the hydraulic index $\mathrm{K}_{3}$, defined as $\left(\mathrm{CaO}+\mathrm{MgO}+\mathrm{Al}_{2} \mathrm{O}_{3}\right) / \mathrm{SiO}_{2}$. Values of $\mathrm{K}_{3}>1$ are an indication of good hydraulic properties (Berra et al., 2015). All WAs was investigated by Berra et al., (2015) and all WAs in the present study, except WCBA, have a hydraulic index above 1. Rajamma et al., (2009a) expected hydraulic reactions of a WA due to a content of $\mathrm{CaO}$ above $25 \%$, substantiated by Cheah and Ramli, (2011b) determining WA to be an active hydraulic binder as it is rich in $\mathrm{CaCO}_{3}$ and $\mathrm{CaO}$. However, none of the WAs in Berra et al., (2015), Cheah and Ramli, (2011b) and Rajamma et al., (2009a) complies with the normative compositional requirements set by EN 197-1, (2011).

206 A CaO- $\mathrm{SiO}_{2}-\mathrm{Al}_{2} \mathrm{O}_{3}$ ternary diagram with the WAs of the present investigation is plotted in figure 2. All mixed and fly WA are located in the area for SCM with potential hydraulic properties (high content of $\mathrm{CaO}$, low content of $\mathrm{SiO}_{2}$ and $\mathrm{Al}_{2} \mathrm{O}_{3}$ ) and WCBA is in the latent 
or slag. The composition of WCFA3 and WMFA2 are located just outside the sketched area for Portland cement, which is hydraulic, thus properties alike Portland cement could be seen for WCFA3 and WMFA2. The ternary diagram shows that all mixed and fly WA comply with the requirements set by EN 197-1, (2011), i.e. they potential have hydraulic activity. Thus there is a possibility for using mixed and fly WA as SCM partially replacing cement in cement-based materials.

\subsubsection{Filler}

Fillers are in principle inert and do not react themselves. However, the addition of WA as a filler could still positively influence the suitability of WA in cement-based materials. An inert filler can contribute to the properties of a cement-based material by filling the intergranular voids between the cement grains in the mixture (Deschner et al., 2012; Moosberg-Bustnes et al., 2004). An inert filler can also contribute by having a heterogeneous nucleation effect, acting as nucleation sites for the hydrates in cement, accelerating the hydration reaction and thus improving the compressive strength development (Lawrence et al., 2005; Moosberg-Bustnes et al., 2004; Ye et al., 2007).

The compliance of WA with the filler limit $(250 \mu \mathrm{m})$ (Herholdt et al., 1985; Moosberg-Bustnes et al., 2004) and category $\mathrm{N}$ described in EN 450-1, (2012) are highly depending on the type of ash. Only the fly ashes WPFA, WCFA2 and WCFA3, comply with category N (EN 450, 2012), and the same three fly ashes have a $>95 \%$ compliance with the filler limit (table 2). Thus, three fly ashes WPFA, WCFA2 and WCFA3 can be expected to contribute to a decrease in porosity and an increase in compressive strength through the filler effect when utilised in cement-based materials.

The ability of fillers to act as nucleation sites depends on the fineness of the particles, the amount of mineral admixture and the affinity of the filler to cement hydrates related to the origin of the mineral admixture (Lawrence et al., 2005). Particles $>215 \mu \mathrm{m}$ can be assumed to be large enough to exclude any heterogeneous nucleation effects (Lawrence et al., 2003; Neville, 1996). This facilitates the fly ashes, and particularly the three fly ashes WPFA, WCFA2 and WCFA3, to have a potential larger contribution to the compressive strength through the heterogeneous nucleation effect, compared to the bottom and mixed WA. Grinding the WAs may lead to an increase in the WAs possibility for utilisation as filler (Berra et al., 2015). 
242 The mineralogical composition was determined by XRD (table 2 and figure 3). Quartz, arcanite

243 and calcite were seen to be the predominant mineral components for seven out of the eleven

244 WAs, which is in accordance with Yeboah et al., (2014). Other detected mineral components 245 were portlandite, sylvite, periclase and lime. WCBA differs from the other WAs by having 246 only quartz and wollastonite as identified mineral components.

247 From the XRD analysis (coal fly ash included for comparison) in figure 3, the amorphous rise 248 was observed from approximately $15^{\circ} 2 \theta$ to $35^{\circ} 2 \theta$. A broad amorphous peak is common in 249 XRD studies of coal fly ash due to the poorly ordered atomic structure of the amorphous glass 250 content of the coal fly ash (Bellotto et al., 1989; van Roode et al., 1987; Yeboah et al., 2014), 251 as seen in figure 3. For all the investigated WA no such peak was observed, thus they contain 252 a very limited (if any) amount of amorphous glass.

253 The lack of amorphous glass is supported by the SEM images, figure 4, for the investigated 254 WA. The SEM images, display all the investigated WA to contain none of the typical glassy 255 aluminosilicate spherical particles, found in commercial coal fly ash (Yeboah et al., 2014). The 256 SEM images, display the investigated WA to consist of large and fibrous wood particles, 257 originating from the biomass (Yeboah et al., 2014). Low content of aluminosilicate leads to a 258 low pozzolanic activity (Shearer, 2014), which is in accordance with the previous findings, 259 stated that pozzolanic activity is expected for the investigates WAs, except for WCBA, based 260 on the content of oxides.

\subsection{Multivariate analysis}

A statistical analysis of experimental data sets can establish trends and correlations in a system, e.g. assessing the possible relations between the inputs and outputs. In a traditional statistical analysis, e.g. multiple regression analysis, the input variables are assumed independent, which can result in biased results of an analysis, if the input variables are correlated (Pedersen et al., 2015). Biased resuts is, e.g. the case for the chloride content and solubility in water of WAs,

267 which are co-dependent (Wang et al., 2001). Statistical analyses coping with possible collinearity between the variables are the multivariate methods principal component analysis 269 (PCA) and partial least squares (PLS) regression, which in addition provides plots of the data compressed to fewer dimensions than the original dataset (Pedersen et al., 2015). 
271 The production parameters for each of the collected WA are given in table 1, defined as the X272 matrix and the measured, individual physicochemical characteristics of the WA are given in 273 tables 2, 3 and 4, defined as the Y-matrix. Combined these tables represent the data set used 274 for the multivariate analysis.

275

276

277

278

279

280

281

282

\subsubsection{Evaluation of physicochemical characteristics of WA by PCA modelling}

PCA is a statistical procedure for identifying differences and similarities in multivariate data. PCA modelling reduces the dimensions of multivariate data by an orthogonal transformation of the variables into a set of linearly uncorrelated variables, referred to as principal components (Voshell et al., 2018). This transformation entails the first principal component to account for as much of the variability from the original data set as possible, and each of the following principal components has the highest variance possible under the constraint that the principal component is orthogonal to the preceding principal component. A detailed description can be found in Jackson, (1991). A loading plot has been obtained by projection of the original variables onto the principal components. The Loading Scatter Plot is used to interpret the relationships between the original variables. In this work, the original variables used for PCA modelling is the physicochemical characteristics of the WAs (Y-matrix), and the obtained Loading Scatter Plot can be seen in figure 1. The influence of each of the original variables on the principal components is reflected by the location of the original variable in the obtained Loading Scatter Plot. Variables with a strong contribution to the variation are projected far from the axis centre (e.g. $\mathrm{Al}_{2} \mathrm{O}_{3}$ and $\mathrm{SiO}_{2}$, figure 1), and variables with minor influenced are projected close to the axis centre (e.g. carbonate, figure 1). Variables, which are positively correlated, are found close to each other (e.g. $\mathrm{Al}_{2} \mathrm{O}_{3}$ and $\mathrm{SiO}_{2}$, figure 1) and variables, which are negatively correlated, are projected opposite each other with respect to the origin of the plot (e.g. high compliance with the filler limit and a high mean particle size, figure 1) (Pedersen et al., 2015). As the physicochemical characteristics of the WA, in this work, are defined as the Y-matrix, the PCA model is referred to as a PCA-Y model.

Expected correlations between the measured physicochemical characteristics of WA can contribute to the validation of the composed Loading Scatter Plot for the PCA-Y model (figure 1), and subsequently the PLS model. The Loading Scatter Plot (figure 1) displays the principal components 1 and 2. The PCA-Y model is based in total on five principal components, resulting in a model with 25 Loading Scatter Plots and $85 \%$ of the correlations between the physicochemical characteristics of WA explained. An example of an expected correlation seen 
in the Loading Scatter Plot (figure 1) is a high amount of particles, complying with the filler limit (particle size $<250 \mu \mathrm{m}$ (Herholdt et al., 1985)) and category $\mathrm{N}$ (maximum $40.0 \%$ by mass of the particles retained on a $45 \mu \mathrm{m}$ sieve $(\mathrm{EN} \mathrm{450,2012)})$. These again correlates with a high specific surface area (SSA) and a low mean size (D50) of the particles, supported by the literature.

Further, the following is displayed by the PCA-Y model:

- The composed PCA-Y model (figure 1) displayed the possible pozzolanic activity (defined as $\sum$ primary oxides (EN 450,2012)) of the investigated WAs to originate only from a high content of $\mathrm{SiO}_{2}$ and $\mathrm{Al}_{2} \mathrm{O}_{3}$, as the WAs have a low content of $\mathrm{Fe}_{2} \mathrm{O}_{3}$. Further, a high pozzolanic activity is seen in the PCA-Y model to entails a low content of $\mathrm{CaO}$ and a low LoI measured at both $550^{\circ} \mathrm{C}$ and $950^{\circ} \mathrm{C}$.

- From the composed PCA-Y model, the hydraulic activity (defined as the $\mathrm{CaO} / \mathrm{SiO}_{2}$ ratio (EN 197-1, 2011)) of the WAs is seen to increase with a high content of particles complying with the filler limit (Herholdt et al., 1985; Moosberg-Bustnes et al., 2004), category N (EN 450,2012 ), and a high SSA and a low LoI at both $550^{\circ} \mathrm{C}$ and $950^{\circ} \mathrm{C}$, and relatively low $\mathrm{pH}$.

- WA with a high content of particles complying with the filler limit (Herholdt et al., 1985; Moosberg-Bustnes et al., 2004) is correlated to a high content of $\mathrm{Fe}_{2} \mathrm{O}_{3}$ and $\mathrm{SO}_{4}{ }^{-2}$, and a low LoI measured at both $550^{\circ} \mathrm{C}$ and $950^{\circ} \mathrm{C}$.

\subsubsection{Relationship between production parameters and physicochemical characteristics of $W A$ evaluated by PLS modelling}

PLS is a multivariate method used for modelling the quantitative relationships between two data matrices, the descriptor matrix (X-matrix) and the response matrix (Y-matrix) (Wold et al., 2001). In this work, a PLS model was conducted in order to see how the production parameters (X-matrix, table 1) influences on the physicochemical characteristics of WA (Ymatrix, tables 2, 3 and 4). The PLS model is based on four principal components, resulting in a model with 16 Loading Scatter Plots and $90 \%$ of the correlations between the production parameters and the physicochemical characteristics of WA explained.

Table 3 summarises the assessment of whether the production parameters and ash type (Xmatrix) included in the model have positive $(+)$ or negative $(-)$ influence response, thus leading to an increase or decrease, respectively, on the measurements for the physicochemical characteristics of WA (Y-matrix). 
334 The relative importance of each of the production parameters included in the PLS model can

335 be described by the variable importance in the projection (VIP) plot. The VIP-plot is constructed with respect to all the responses (Y-matrix) and the projections (X-matrix).

337 Production parameters with VIP-values above one are considered to be most relevant for 338 explaining the physicochemical characteristics of WA (Pedersen et al., 2015). VIP-plot for the 339 production parameters, included in this work, is shown in table 4. The production parameters 340 with VIP-values above 1 are the ash types ' $\mathrm{B}$ ' and ' $\mathrm{F}$ ', the combustion methods 'CFB' and 341 'grate', and the biofuel 'chips'. Thus, these production parameters have, according to the 342 conducted model, the largest influence on the physiochemical characteristics of WA 343 (response). The production parameters ash type ' $\mathrm{M}$ ', the types of biofuel 'chips + powder' and 344 'pellets', origin of biofuel 'log' and 'tree', combustion temperature and initial water content of 345 the biofuel had VIP-values between 0.5 and 1, indicating a moderate influence on the 346 physiochemical characteristics of WA (response).

347 The presented PLS model and VIP-values corresponds to the findings of S. V. Vassilev et al., 348 (2010) of the combustion technology to have the most significant impact on the properties of 349 biomass ash (ash types excluded). S. V. Vassilev et al., (2010) further concluded that WA 350 originating from land clearing wood, pine chips and wood residue results in WAs complying 351 with the limit for the primary oxides set by EN 450-1, (2012) and WA, originating from elm 352 bark, olive wood, poplar bark, spruce bark and willow results in the WA complying with the 353 limit for hydraulic activity set by EN 197-1, (2011). These conclusions corresponds to the 354 findings in the presented PLS model, where the origin of biofuel is found to have the largest 355 influence on the composition of oxides.

356 The particle size, governing the amount of WA particles to comply with the filler limit, (table 357 2), is highly dependent on the type of ash, where fly ash has the smallest particles (Cheah and 358 Ramli, 2011a). In addition, the type of biofuel and the combustion temperature also influences 359 the particle size. Wood pellets and high combustion temperature generally facilitates smaller 360 particles, substantiated by Cheah and Ramli, (2011a) and Lecuyer et al., (1996). This 361 correlation is due to the link between the combustion technology and combustion temperature 362 (S. V. Vassilev et al., 2010). characteristics of WA for utilisation in cement-based materials by PLS modelling 
365 To identify which production parameters results in a WA suitable in cement-based materials, 366 the PLS model is compared with the chemical requirements set by (EN 450, 2012) and (EN 367 197-1, 2011), see tables 2 and 4. The standard (EN 450, 2012) only covers fly ashes, thus the 368 ash types in the PLS model are neglected in the following.

\subsubsection{Pozzolanic activity}

370 The following points relate the experimental results to the chemical requirements for fly ash with pozzolanic properties set by EN 450-1, (2012):

372

- CFB combustion and biofuel originating from whole trees processed into wood chips as biofuel contributes to a high content of $\mathrm{SiO}_{2}$ and thus a high content of primary oxides.

- CFB combustion with a low combustion temperature and biofuel originating from whole trees processed into a combination of wood chips and wood powder as biofuel contributes to a low content of $\mathrm{CaO}$.

- Wood chips as biofuel contribute to a low content of $\mathrm{MgO}$.

- CFB combustion and biofuel originating from wood logs contribute to a low content of $\mathrm{P}_{2} \mathrm{O}_{5}$.

- A low combustion temperature facilitates a low content of $\mathrm{SO}_{3}$.

- Biofuel originating from whole trees processed into wood pellets as biofuel contributes to a low content of $\mathrm{Cl}^{-}$.

- CFB combustion with a low combustion temperature and biofuel originating from wood logs contribute to a low LoI measured at $950{ }^{\circ} \mathrm{C}$.

\subsubsection{Hydraulic activity}

The following points relate to the chemical requirements for fly ash with hydraulic properties set by EN 197-1, (2011):

- Biofuel originating from whole trees processed into wood chips as biofuel contributes to a high content of $\mathrm{SiO}_{2}$ and $\mathrm{CaO}$.

- Wood pellets as biofuel contribute to a high content of $\mathrm{MgO}$. However, the content of $\mathrm{MgO}$ complies with the limit set by EN 197-1, (2011) for both wood pellets, chips and chips + powder as biofuel.

\subsubsection{Filler}


394 The following points relate to the chemical requirements for fly ash complying with the filler

395 limit and category N set by EN 450-1, (2012):

396

397

398

399

400

401

402

403

404

405

406

407

408

409

410

411

412

413

414

415

416

417

418

419

420

421

422

- A high combustion temperature and wood pellets used as biofuel contribute to a high amount of WA particles complying with the filler limit.

- A low initial water content facilitates a WA complying with category N.

\subsection{General discussion on utilisation of WA}

Based on the physical and chemical characterization of the wood ashes this study shows that WAs have potential for utilisation as a SCM in cement-based materials with hydraulic properties. However, castings of concrete are needed to explore the full potential. To meet industrial use it is necessary to either reconsider the current standard EN 450-1, (2012) or establish a new standard taking into account, among others, the hydraulic properties and the alkali content.

Besides utilisation as a SCM, WA can be utilised as fertiliser. Spreading of WA and recycling of nutrients from wood combustion in the forest counteracts the export of nutrients from the forest when harvesting for energy production, thus creating a closed loop of the nutrients returning to the forest promoting forest growth (Ingerslev et al., 2011; Pitman, 2006). The suitability of WA as fertiliser depends on the retained nutrients in the ash e.g. potassium, phosphorous, calcium and magnesium, which must be relatively high and on the content of heavy metals e.g. arsenic, cadmium, lead, chromium and nickel, which must meet limiting values (Danish Environmental Protection Agency, 2017; Ingerslev et al., 2011). The Danish Environmental Protection Agency, 2017; Ingerslev et al., 2011 also sets limit for the conductivity of the WA of maximum $3600 \mathrm{mS} / \mathrm{m}$. The retained nutrients were not included in this study; however, based on the presented model and the measured conductivity, bottom or mixed ash and fly ash only originating from CFB combustion are suitable for recirculation to the forests.

It is not an either-or weather WAs can be used in concrete or as fertilizer. Some of the WAs may find use in concrete or as fertilizer, dependent on their characteristics and local conditions. When considering utilisation of the raw material WA, the utilization with the largest environmental and economic value as possible should be chosen.

\section{Conclusion}


423 In this study, WAs from eleven different plants were characterised and PCA and PLS modelling

424 were performed in order to assess the linkage between the production parameters and the 425 physiochemical characteristics of WA. The most important conclusion from the PLS model 426 was the combustion method and type of ash (B or F) to have the largest influence on the WA 427 characteristics. Based on the PLS model, a WA originating from CFB combustion of wood 428 chips made from whole trees (logs, bark, buds and pine needles) at low temperatures are the 429 most optimal type of WA when utilised as an SCM with pozzolanic activity, as these 430 combustion parameters facilitate a higher content of primary oxides. A wood fly ash originating 431 from the combustion of wood chips made from whole trees is the most optimal type of WA 432 when utilised as an SCM with hydraulic activity. When used as filler, WA originating from 433 high-temperature combustion with wood pellets used as a biofuel has the best characteristics. 434 Low initial water content of the biofuel content facilitates the WA to comply with category N, 435 which is consistent with wood pellets facilitating a low particle size, as wood pellets contain 436 significantly less water than wood chips and wood chips + powder.

437 None of the investigated fly and mixed ashes complied with the normative compositional 438 requirements for indications of pozzolanic activity of $\sum$ primary oxides $>70 \%$ (EN 450, 2012). 439 Thus all of the investigated WAs have little or no pozzolanic potential, latter, which is primarily 440 seen for, WAs from grate combustion. The opposite tendency is seen for the hydraulic activity, 441 were all mixed and fly ashes complied with the normative compositional requirements, thus 442 being able to set and harden, while submerged in water, by forming cementitious products in a 443 hydration reaction. Only three of the investigated WAs are found to comply with the filler limit, 444 thus expected to contribute to the compressive strength through the filler effect.

\section{5. Acknowledgement}

447 The reported work was financially supported partially by the Department of Civil Engineering 448 at the Technical University of Denmark and Emineral A/S and partially by scholarships granted 449 by P.A.Fiskers Foundation, The Toubro Foundation, Danielsen's Foundation, Spirekassen, 450 EKOKEM and Martha and Paul Kerrn-Jespersens Foundation. Halsnæs Supply A/S, Køge 451 Power Plant, Svebølle Viskinge District Heating Company, HOFOR Amagerværket, 452 Värtaverket Combined Heat and Power Plant and Herning Power station are acknowledged for 
supplying the investigated wood ashes. Kristine Bondo Pedersen is acknowledged for her great teachings regarding the multivariate data analysis.

\section{References}

ASTM International C125-15a, 2003. Standard Terminology Relating to Concrete and Concrete Aggregates i, 1-4.

Bellotto, M., Boni, C., Caridi, A., Cereda, E., Chemelli, C., Marcazzan, G.M.B., Parmigiani, F., Scagliotiti, M., Bellagamba, B., 1989. Analysis of Coal Fly Ash by Bulk and Surface Characterization Techniques. MRS Proc. 178, 45.

Berra, M., Mangialardi, T., Paolini, A.E., 2015. Reuse of woody biomass fly ash in cementbased materials. Constr. Build. Mater. 76, 286-296.

CEN (European Committee for Standardization), 2009. European Standard EN 14775: Solid biofuels - Determination of ash content.

Cheah, C.B., Ramli, M., 2011a. The implementation of wood waste ash as a partial cement replacement material in the production of structural grade concrete and mortar: An overview. Resour. Conserv. Recycl. 55, 669-685.

Cheah, C.B., Ramli, M., 2011b. Properties of high calcium wood ash and densified silica fume blended cement. Int. J. Phys. Sci. 6, 6596-6606.

Cheah, C.B., Ramli, M., 2011c. The implementation of wood waste ash as a partial cement replacement material in the production of structural grade concrete and mortar: An overview. Resour. Conserv. Recycl. 55, 669-685.

Chowdhury, S., Maniar, A., Suganya, O.M., 2015. Strength development in concrete with wood ash blended cement and use of soft computing models to predict strength parameters. J. Adv. Res. 6, 907-913.

Christensen, J.H., Hansen, A.B., Karlson, U., Mortensen, J., Andersen, O., 2005. Multivariate statistical methods for evaluating biodegradation of mineral oil. J. Chromatogr. A 1090, $133-145$. 
Dahl, O., Nurmesniemi, H., Pöykiö, R., Watkins, G., 2009. Comparison of the characteristics of bottom ash and fly ash from a medium-size (32 MW) municipal district heating plant incinerating forest residues and peat in a fluidized-bed boiler. Fuel Process. Technol. 90, $871-878$.

Danish Environmental Protection Agency, 2017. Bekendtgørelse om anvendelse af bioaske til jordbrugsformål (Bioaskebekendtgørelsen) (in Danish). Danish Environ. Prot. Agency $1-16$.

Deschner, F., Winnefeld, F., Lothenbach, B., Seufert, S., Schwesig, P., Dittrich, S., GoetzNeunhoeffer, F., Neubauer, J., 2012. Hydration of Portland cement with high replacement by siliceous fly ash. Cem. Concr. Res. 42, 1389-1400.

Elinwa, A.U., Mahmood, Y.A., 2002. Ash from timber waste as cement replacement material. Cem. Concr. Compos. 24, 219-222.

Emineral A/S, 2019. Emineral A/S [WWW Document]. URL http://www.emineral.dk/

EN 196-2, 2005. Methods of testing cement - Part 2: Chemical analysis of cement.

EN 197-1, 2011. Cement - Part 1: Composition, specifications and conformity criteria for common cements.

EN 450, 2012. Fly ash for concrete - Part 1: Definition, specifications and conformity criteria.

Etiégni, L., Campbell, A.G., 1991. Physical and chemical characteristics of wood ash. Bioresour. Technol. 37, 173-178.

Hamid, Y.S.A., 2009. Dissolution kinetics of carbonates in soil. Szent István University.

Herholdt, A.D., Justesen, C.F.P., Christensen, P.N., Nielsen, A., 1985. Beton-Bogen (In Danish). Cementfabrikkernes tekniske oplysningskontor, Aalborg Portland.

Illikainen, M., Tanskanen, P., Kinnunen, P., Körkkö, M., Peltosaari, O., Wigren, V., Österbacka, J., Talling, B., Niinimäki, J., 2014. Reactivity and self-hardening of fly ash from the fluidized bed combustion of wood and peat. Fuel 135, 69-75.

Ingerslev, M., Skov, S., Sevel, L., Pedersen, L.B., 2011. Element budgets of forest biomass combustion and ash fertilisation - A Danish case-study. Biomass and Bioenergy 35, 
507

508

509

510

511

512

513

514

515

516

517

518

519

520

521

522

523

524

525

526

527

528

529

530

532

2697-2704.

International Energy Agency (IEA), 2007. Tracking Industrial Energy Efficiency and CO2 Emissions.

Jackson, J.E., 1991. A User's Guide To Principal Components, John Willy \& Sons, Inc. New York.

Kirkelund, G.M., Ottosen, L.M., Jensen, P.E., Goltermann, P., 2016. Greenlandic waste incineration fly and bottom ash as secondary resource in mortar. Int. J. Sustain. Dev. Plan. 11, 719-728.

Lanzerstorfer, C., 2015. Chemical composition and physical properties of filter fly ashes from eight grate-fired biomass combustion plants. J. Environ. Sci. (China) 30, 191-197.

Lawrence, P., Cyr, M., Ringot, E., 2005. Mineral admixtures in mortars effect of type, amount and fineness of fine constituents on compressive strength. Cem. Concr. Res. 35, 1092-1105.

Lawrence, P., Cyr, M., Ringot, E., 2003. Mineral admixtures in mortars Effect of inert materials on short-term hydration. Cem. Concr. Res. 33, 1939-1947.

Lecuyer, I., Bicocchi, S., Ausset, P., Lefevre, R., 1996. Physico-Chemical Characterization and Leaching 1, 15-28.

Lothenbach, B., Scrivener, K., Hooton, R.D., 2011. Supplementary cementitious materials. Cem. Concr. Res. 41, 1244-1256.

McKendry, P., 2002. Energy production from biomass (part 1): overview of biomass. Bioresour. Technol 83, 37-46.

Moosberg-Bustnes, H., Lagerblad, B., Forssberg, E., 2004. The function of fillers in concrete. Mater. Struct. 37, 74-81.

Neslen, A., 2017. The end of coal: EU energy companies pledge no new plants from 2020 (Accessed 16th of November, 2018). Guard.

Neville, A.M., 1996. Properties of concrete, 4th ed. Wiley, New York. 
Pedersen, K.B., Kirkelund, G.M., Ottosen, L.M., Jensen, P.E., Lejon, T., 2015. Multivariate methods for evaluating the efficiency of electrodialytic removal of heavy metals from polluted harbour sediments. J. Hazard. Mater. 283, 712-720.

Peyronnard, O., Benzaazoua, M., 2011. Estimation of the cementitious properties of various industrial by-products for applications requiring low mechanical strength. Resour. Conserv. Recycl. 56, 22-33.

Pitman, R.M., 2006. Wood ash use in forestry - A review of the environmental impacts. Forestry $79,563-588$.

Rajamma, R., Ball, R.J., Tarelho, L.A.C., Allen, G.C., Labrincha, J.A., Ferreira, V.M., 2009a. Characterisation and use of biomass fly ash in cement-based materials. J. Hazard. Mater. $172,1049-1060$.

Rajamma, R., Ball, R.J., Tarelho, L.A.C., Allen, G.C., Labrincha, J.A., Ferreira, V.M., 2009b. Characterisation and use of biomass fly ash in cement-based materials. J. Hazard. Mater. 172, 1049-1060.

Ramos, T., Matos, A.M., Sousa-Coutinho, J., 2013. Mortar with wood waste ash: Mechanical strength carbonation resistance and ASR expansion. Constr. Build. Mater. 49, 343-351.

Schneider, M., Romer, M., Tschudin, M., Bolio, H., 2011. Sustainable cement productionpresent and future. Cem. Concr. Res. 41, 642-650.

Shearer, C.R., 2014. The Productive Reuse of Coal, Biomass and the Productive Reuse of Coal, Biomass and Co-Fired Fly Ash. Georgia Institute of Technology.

Siddique, R., 2012. Utilization of wood ash in concrete manufacturing. Resour. Conserv. Recycl. 67, 27-33.

Siddique, R., 2008. Waste Materials and By-Products in Concrete. Springer Berlin Heidelberg, Berlin, Heidelberg.

Snellings, R., Mertens, G., Elsen, J., 2012. Supplementary Cementitious Materials. Rev. Mineral. Geochemistry 74, 211-278.

Teixeira, E.R., Mateus, R., Camõesa, A.F., Bragança, L., Branco, F.G., 2016. Comparative 
environmental life-cycle analysis of concretes using biomass and coal fly ashes as partial cement replacement material. J. Clean. Prod. 112, 2221-2230.

Udoeyo, F.F., Inyang, H., Young, D.T., Oparadu, E.E., 2006. Potential of wood waste ash as an additive in concrete. J. Mater. Civ. Eng. 18, 605-611.

van Loo, S., Koppejan, J., 2010. The Handbook of Biomass Combustion and Co-firing. Taylor \& Francis Ltd.

van Roode, M., Douglas, E., Hemmings, R.T., 1987. X-ray diffraction measurement of glass content in fly and slags. Cem. Concr. Res. 17, 183-197.

Vassilev, S. V., Baxter, D., Andersen, L.K., Vassileva, C.G., 2010. An overview of the chemical composition of biomass. Fuel 89, 913-933.

Vassilev, S. V., Baxter, D., Vassileva, C.G., 2014. An overview of the behaviour of biomass during combustion: Part II. Ash fusion and ash formation mechanisms of biomass types. Fuel 117, 152-183.

Vassilev, S. V, Baxter, D., Andersen, L.K., Vassileva, C.G., 2010. An overview of the chemical composition of biomass. Fuel 89, 913-933.

Voshell, S., Mäkelä, M., Dahl, O., 2018. A review of biomass ash properties towards treatment and recycling. Renew. Sustain. Energy Rev. 96, 479-486.

Wang, K.S., Chiang, K.Y., Lin, K.L., Sun, C.J., 2001. Effects of a water-extraction process on heavy metal behavior in municipal solid waste incinerator fly ash. Hydrometallurgy $62,73-81$.

Wig, R.J., 1913. The Progress of the Work of the Bureau of Standards in Cement and Concrete. ACI J. Proc. 9.

Wold, S., Sjöström, M., Eriksson, L., 2001. PLS-regression: A basic tool of chemometrics. Chemom. Intell. Lab. Syst. 58, 109-130.

Ye, G., Liu, X., De Schutter, G., Poppe, A.M., Taerwe, L., 2007. Influence of limestone powder used as filler in SCC on hydration and microstructure of cement pastes. Cem. Concr. Compos. 29, 94-102. 
589 Table 1. Production parameters and ash type (X-variables for multivariate statistical analysis)

\begin{tabular}{lcccccc}
\hline Ash type & $\begin{array}{c}\text { Combustion } \\
\text { method }\end{array}$ & $\begin{array}{c}\text { Initial water } \\
\text { content [\%] }\end{array}$ & Type of biofuel & $\begin{array}{c}\text { Origin of } \\
\text { biofuel }\end{array}$ & $\begin{array}{c}\text { Combustion } \\
\text { temperature }\left[{ }^{\circ} \mathbf{C}\right]\end{array}$ \\
\hline WCBA & Bottom & CFB & $24-40$ & Wood Chips & Whole trees & $760-930$ \\
WPMA & Mixed & Grate & $5-8$ & Wood Pellets & Logs & 800 \\
WCMA1 & Mixed & Grate & $35-45$ & Wood Chips & Logs & $800-900$ \\
WCMA2 & Mixed & Grate & $35-50$ & Wood Chips & Whole trees & $800-900$ \\
WCMA3 & Mixed & Grate & $40-45$ & Wood Chips & Logs & $800-900$ \\
WPFA & Fly & Grate & $5-8$ & Wood Pellets & Logs & $1,000-1,100$ \\
WCFA1 & Fly & Grate & $35-50$ & Wood Chips & Whole trees & $800-900$ \\
WCFA2 & Fly & Grate & $40-45$ & Wood Chips & Logs & $800-900$ \\
WCFA3 & Fly & CFB & $25-40$ & Wood Chips & Whole trees & $760-930$ \\
WMFA1 & Fly & Grate & $25-50$ & Wood Chips & Whole trees & $900-1,000$ \\
& & & and Powder & & $1,000-1,100$ \\
WMFA2 & Fly & Grate & $40-45$ & Wood Chips & Whole trees & \\
\hline
\end{tabular}

590

591 Table 2. Chemical composition and physical characteristics of investigated WA (Y-variables for multivariate 592 statistical analysis) and mineralogical composition. * For category C. \pm defines the standard deviation. 593 Requirements for fly ash utilised in cement-based materials (EN 450, 2012), requirements for hydraulic activity 594 (EN 197-1, 2011) and values from literature (Berra et al., 2015; Cheah and Ramli, 2011b, 2011c; Chowdhury et 595 al., 2015; Dahl et al., 2009; Elinwa and Mahmood, 2002; Illikainen et al., 2014; Lanzerstorfer, 2015; Peyronnard 596 and Benzaazoua, 2011; Rajamma et al., 2009b; Ramos et al., 2013; Siddique, 2008; Udoeyo et al., 2006; Vassilev 597 et al., 2014; S. V Vassilev et al., 2010; Yeboah et al., 2014) are added for comparison.

598

\begin{tabular}{|c|c|c|c|c|c|c|c|c|c|c|c|c|c|c|}
\hline & WCBA & WPMA & $\begin{array}{c}\text { WCMA } \\
1 \\
\end{array}$ & $\begin{array}{c}\text { WCMA } \\
2 \\
\end{array}$ & $\begin{array}{c}\text { WCMA } \\
3 \\
\end{array}$ & WPFA & $\begin{array}{c}\text { WCFA } \\
1 \\
\end{array}$ & $\begin{array}{c}\text { WCFA } \\
2 \\
\end{array}$ & $\begin{array}{c}\text { WCFA } \\
3 \\
\end{array}$ & WMFA1 & WMFA2 & $\begin{array}{c}\text { EN 450-1, } \\
(2012)\end{array}$ & $\begin{array}{c}\text { EN 197-1, } \\
\text { (2011) }\end{array}$ & $\begin{array}{c}\text { Literary } \\
\text { review }\end{array}$ \\
\hline \multicolumn{15}{|c|}{ Chemical composition (\%) } \\
\hline $\mathrm{SiO}_{2}$ & 57.8 & 3.4 & 3.9 & 4.1 & 9.4 & 4.3 & 3.6 & 1.7 & 19.3 & 5.3 & 10.3 & $>25.0$ & & $1.74-73.01$ \\
\hline $\mathrm{Al}_{2} \mathrm{O}_{3}$ & 4.9 & 0.9 & 1.5 & 0.9 & 1.3 & 0.9 & 0.6 & 0.4 & 3.4 & 0.9 & 1.5 & & & $0.12-28$ \\
\hline $\mathrm{Fe}_{2} \mathrm{O}_{3}$ & 1.1 & 1.6 & 0.6 & 0.7 & 1.0 & 2.1 & 0.9 & 1.0 & 2.1 & 1.1 & 1.6 & & & $0.09-27.9$ \\
\hline $\begin{array}{l}\Sigma \text { primary } \\
\text { oxides }\end{array}$ & 63.8 & 5.9 & 5.9 & 5.7 & 11.7 & 7.4 & 5.1 & 3.1 & 24.8 & 7.4 & 13.4 & $>70.0$ & & \\
\hline $\mathrm{CaO} / \mathrm{SiO}_{2}(-)$ & 3.6 & 11.1 & 8.6 & 19.5 & 5.7 & 15.0 & 13.6 & 36.2 & 2.2 & 6.3 & 3.1 & & $>2$ & \\
\hline $\mathrm{CaO}$ & 16.0 & 37.8 & 33.6 & 79.8 & 53.2 & 64.4 & 49.0 & 61.6 & 41.7 & 33.6 & 31.5 & $<10.0$ & & $1.16-83.46$ \\
\hline $\mathrm{MgO}$ & 1.5 & 4.1 & 2.0 & 2.7 & 1.5 & 4.5 & 2.8 & 2.2 & 3.3 & 0.8 & 4.0 & $<4.0$ & $<5.0$ & $0.7-14.57$ \\
\hline $\mathrm{K}_{2} \mathrm{O}$ & 8.9 & 17.0 & 16.9 & 9.9 & 4.3 & 22.9 & 10.1 & 38.5 & 6.3 & 10.0 & 14.2 & & & $0.11-31.99$ \\
\hline $\mathrm{Na}_{2} \mathrm{O}$ & 0.0 & 1.1 & 1.1 & 0.7 & 0.7 & 0.9 & 0.8 & 2.7 & 1.2 & 2.6 & 1.9 & & & $0.08-29.82$ \\
\hline $\mathrm{P}_{2} \mathrm{O}_{5}$ & $<0.5$ & 2.7 & 1.1 & 3.7 & 1.1 & 2.5 & 3.2 & 2.5 & 2.5 & 1.4 & 3.0 & $<5.0$ & & $0.07-13.01$ \\
\hline $\mathrm{TiO}_{2}$ & 0.2 & 0.3 & 0.0 & 0.0 & 0.1 & 0.0 & 0.0 & 0.0 & 0.2 & 0.1 & 0.2 & & & $0.01-1.2$ \\
\hline $\mathrm{SO}_{3}$ & 0.2 & 3.0 & 0.7 & 1.2 & 0.7 & 6.0 & 2.5 & 19.2 & 4.2 & 3.5 & 4.5 & $<3.0$ & & $0.05-12.5$ \\
\hline $\mathrm{Cl}^{-}$ & $\begin{array}{c}0.001 \pm \\
0.0002\end{array}$ & $\begin{array}{c}0.9 \pm \\
0.03\end{array}$ & $\begin{array}{l}1.0 \pm \\
0.01\end{array}$ & $\begin{array}{l}0.3 \pm \\
0.003\end{array}$ & $\begin{array}{c}0.05 \pm \\
0.005\end{array}$ & $\begin{array}{c}0.5 \pm \\
0.01\end{array}$ & $\begin{array}{c}0.6 \pm \\
0.08\end{array}$ & $\begin{array}{c}21.6 \pm \\
1.2\end{array}$ & $\begin{array}{l}0.5 \pm \\
0.004\end{array}$ & $1.83 \pm 0.2$ & $\begin{array}{c}0.52 \pm \\
0.008\end{array}$ & $<0.1$ & & $0.1-1.74$ \\
\hline $\mathrm{SO}_{4}^{-2}$ & $\begin{array}{c}0.02 \pm \\
0.0\end{array}$ & $\begin{array}{c}4.1 \pm \\
0.1\end{array}$ & $\begin{array}{c}0.43 \pm \\
0.0\end{array}$ & $1.3 \pm 0.0$ & $\begin{array}{c}0.2 \pm \\
0.0\end{array}$ & $\begin{array}{c}5.6 \pm \\
0.1\end{array}$ & $\begin{array}{c}3.4 \pm \\
0.4\end{array}$ & $\begin{array}{c}10.2 \pm \\
0.05\end{array}$ & $\begin{array}{c}1.8 \pm \\
0.0\end{array}$ & $3.36 \pm 0.0$ & $4.2 \pm 0.1$ & & & $0.12-0.96$ \\
\hline LoI, $550^{\circ} \mathrm{C}$ & $\begin{array}{c}0.0 \pm \\
0.0\end{array}$ & $\begin{array}{c}0.7 \pm \\
0.4\end{array}$ & $9.8 \pm 1.0$ & $1.9 \pm 1.2$ & $\begin{array}{c}1.7 \pm \\
0.3\end{array}$ & $\begin{array}{c}0.5 \pm \\
0.3\end{array}$ & $\begin{array}{c}8.4 \pm \\
0.4\end{array}$ & $\begin{array}{c}1.0 \pm \\
0.3\end{array}$ & $\begin{array}{c}0.8 \pm \\
0.0\end{array}$ & $9.3 \pm 1.5$ & $7.2 \pm 0.1$ & & & $<0.5$ \\
\hline $\mathrm{LoI}, 950^{\circ} \mathrm{C}$ & $\begin{array}{c}0.4 \pm \\
0.1\end{array}$ & $\begin{array}{c}9.9 \pm \\
0.2 \\
\end{array}$ & $\begin{array}{c}23.2 \pm \\
1.5\end{array}$ & $\begin{array}{c}19.7 \pm \\
1.8 \\
\end{array}$ & $\begin{array}{c}7.6 \pm \\
0.3 \\
\end{array}$ & $\begin{array}{c}15.3 \pm \\
0.3\end{array}$ & $\begin{array}{c}25.0 \pm \\
0.2 \\
\end{array}$ & $\begin{array}{c}16.7 \pm \\
0.1 \\
\end{array}$ & $\begin{array}{c}10.2 \pm \\
0.1\end{array}$ & $25.4 \pm 1.1$ & $18.3 \pm 0.2$ & $<9.0^{*}$ & & $0.66-95.9$ \\
\hline \multicolumn{15}{|c|}{ Physical characteristics } \\
\hline $\begin{array}{l}\text { Mean particle } \\
\text { size, } \mathrm{D}_{50}(\mu \mathrm{m})\end{array}$ & $\begin{array}{c}184.5 \pm \\
1.8\end{array}$ & $\begin{array}{c}94.5 \pm \\
12.8\end{array}$ & $\begin{array}{c}257.1 \pm \\
29.9\end{array}$ & $\begin{array}{c}65.1 \pm \\
3.6\end{array}$ & $\begin{array}{c}534.7 \pm \\
54.2\end{array}$ & $\begin{array}{c}18.3 \pm \\
0.3\end{array}$ & $\begin{array}{c}61.7 \pm \\
3.9\end{array}$ & $\begin{array}{c}10.5 \pm \\
0.1\end{array}$ & $\begin{array}{c}10.8 \pm \\
0.0\end{array}$ & $\begin{array}{c}273.9 \pm \\
29.4\end{array}$ & $\begin{array}{c}90.2 \pm \\
11.0\end{array}$ & & & $3.2-1,440$ \\
\hline
\end{tabular}




\begin{tabular}{|c|c|c|c|c|c|c|c|c|c|c|c|c|}
\hline $\begin{array}{l}\text { Spread of } \\
\text { particle size } \\
\text { distribution } \\
(\mu \mathrm{m})\end{array}$ & $\begin{array}{l}2.5- \\
631.0\end{array}$ & $\begin{array}{c}1.3- \\
2,187.8\end{array}$ & $\begin{array}{c}1.4- \\
2,187.8\end{array}$ & $\begin{array}{c}1.3- \\
2,187.8\end{array}$ & $\begin{array}{c}1.3- \\
2,187.8\end{array}$ & $\begin{array}{l}0.5- \\
549.5\end{array}$ & $\begin{array}{c}1.0- \\
2,187.8\end{array}$ & $\begin{array}{l}0.4- \\
478.6\end{array}$ & $\begin{array}{l}0.6- \\
478.6\end{array}$ & $\begin{array}{c}1.1- \\
2,187.8\end{array}$ & $\begin{array}{c}1.3- \\
2,187.8\end{array}$ & $30-600$ \\
\hline Specific & $0.04 \pm$ & $0.2 \pm$ & $0.1 \pm 0.0$ & $0.3 \pm$ & $0.1 \pm$ & $0.7 \pm$ & $0.4 \pm$ & $1.2 \pm$ & $1.0 \pm$ & $0.1 \pm 0.02$ & $0.2 \pm 0.02$ & \\
\hline $\begin{array}{l}\text { Surface Area } \\
\left(\mathrm{m}^{2} / \mathrm{g}\right)\end{array}$ & 0.02 & 0.02 & & 0.04 & 0.01 & 0.01 & 0.03 & 0.01 & 0.01 & & & \\
\hline $\mathrm{pH}$ & $\begin{array}{c}11.9 \pm \\
0.0\end{array}$ & $\begin{array}{c}12.3 \pm \\
0.1\end{array}$ & $\begin{array}{c}13.0 \pm \\
0.1\end{array}$ & $\begin{array}{c}12.8 \pm \\
0.0\end{array}$ & $\begin{array}{c}12.6 \pm \\
0.0\end{array}$ & $\begin{array}{c}13.1 \pm \\
0.0\end{array}$ & $\begin{array}{c}13.0 \pm \\
0.1\end{array}$ & $\begin{array}{c}12.7 \pm \\
0.0\end{array}$ & $\begin{array}{c}12.7 \pm \\
0.0\end{array}$ & $12.8 \pm 0.0$ & $\begin{array}{c}13.3 \pm \\
0.01\end{array}$ & $10.10-12.5$ \\
\hline $\begin{array}{l}\text { Conductivity } \\
\left(\mathrm{mS} \mathrm{m}^{-1}\right)\end{array}$ & $\begin{array}{c}184.6 \pm \\
7.8\end{array}$ & $\begin{array}{l}1,894.3 \\
\pm 125.0\end{array}$ & $\begin{array}{c}3,053.3 \pm \\
100.7\end{array}$ & $\begin{array}{c}2,253.3 \pm \\
196.3\end{array}$ & $\begin{array}{l}1,067.7 \\
\pm 103.8\end{array}$ & $\begin{array}{c}4,760 \pm \\
535.1\end{array}$ & $\begin{array}{c}4,980.0 \\
\pm \\
1,496.4\end{array}$ & $\begin{array}{l}3,976.7 \\
\pm 141.9\end{array}$ & $\begin{array}{c}2,380 \pm \\
10.0\end{array}$ & $\begin{array}{c}3,950.0 \pm \\
364.3\end{array}$ & $\begin{array}{c}12,160 \pm \\
317.6\end{array}$ & \\
\hline $\mathrm{CaCO}_{3}(\%)$ & $\begin{array}{c}21.4 \pm \\
0.2\end{array}$ & $\begin{array}{c}27.6 \pm \\
0.5\end{array}$ & $\begin{array}{c}19.3 \pm \\
0.3\end{array}$ & $\begin{array}{c}16.0 \pm \\
0.9\end{array}$ & $\begin{array}{c}12.1 \pm \\
0.4\end{array}$ & $\begin{array}{c}26.5 \pm \\
3.4\end{array}$ & $\begin{array}{c}16.9 \pm \\
0.2\end{array}$ & $\begin{array}{c}21.1 \pm \\
0.3\end{array}$ & $\begin{array}{c}1.5 \pm \\
0.2\end{array}$ & $22.2 \pm 0.4$ & $16.1 \pm 0.3$ & \\
\hline $\begin{array}{l}\text { Water } \\
\text { solubility (\%) }\end{array}$ & $\begin{array}{c}0.5 \pm \\
0.4\end{array}$ & $\begin{array}{c}14.1 \pm \\
0.2\end{array}$ & $\begin{array}{c}11.8 \pm \\
0.6\end{array}$ & $9.0 \pm 0.5$ & $\begin{array}{c}2.2 \pm \\
0.2\end{array}$ & $\begin{array}{c}17.9 \pm \\
3.4\end{array}$ & $\begin{array}{c}8.9 \pm \\
0.5\end{array}$ & $\begin{array}{c}43.6 \pm \\
1.2\end{array}$ & $\begin{array}{c}6.8 \pm \\
0.4\end{array}$ & $14.8 \pm 0.3$ & $24.1 \pm 1.2$ & \\
\hline \multicolumn{13}{|c|}{ Percentage of WA complying with the filler limit and compliance with Category $N(\mathrm{EN} 450,2012)($ Yes $=$ comply $/$ No $=$ does not comply $)$} \\
\hline $\begin{array}{l}\text { Percentage } \\
\text { complying with } \\
\text { the filler limit } \\
(<250 \mu \mathrm{m}) \\
\text { (Herholdt et al., } \\
1985 \text {; } \\
\text { Moosberg- } \\
\text { Bustnes et al., } \\
2004)\end{array}$ & $72 \pm 0.6$ & $78 \pm 4.6$ & $\begin{array}{c}49.7 \pm \\
2.5\end{array}$ & $\begin{array}{c}72.3 \pm \\
1.9\end{array}$ & $\begin{array}{c}31.3 \pm \\
2.1\end{array}$ & $\begin{array}{c}98.2 \pm \\
0.7\end{array}$ & $\begin{array}{c}65.7 \pm \\
1.0\end{array}$ & $\begin{array}{c}95.5 \pm \\
0.4\end{array}$ & $\begin{array}{c}98.6 \pm \\
0.2\end{array}$ & $48.5 \pm 1.9$ & $76.6 \pm 4.9$ & \\
\hline $\begin{array}{l}\text { Complying } \\
\text { with category N } \\
\text { (EN 450, 2012) }\end{array}$ & No & No & No & No & No & Yes & No & Yes & Yes & No & No & \\
\hline \multicolumn{13}{|c|}{ Mineralogical compositions of investigated $W A$ determined by XRD analysis. $X$ marks detected minerals. } \\
\hline Quartz $\left(\mathrm{SiO}_{2}\right)$ & $\mathrm{X}$ & $\mathrm{X}$ & $\mathrm{X}$ & $\mathrm{X}$ & $\mathrm{X}$ & $\mathrm{X}$ & $\mathrm{X}$ & & $\mathrm{X}$ & $\mathrm{X}$ & $\mathrm{X}$ & \\
\hline $\begin{array}{l}\text { Portlandite } \\
\left(\mathrm{Ca}(\mathrm{OH})_{2}\right)\end{array}$ & & & $\mathrm{X}$ & $\mathrm{x}$ & $\mathrm{X}$ & & & $\mathrm{X}$ & & & & \\
\hline $\begin{array}{l}\text { Calcite } \\
\left(\mathrm{Ca}\left(\mathrm{CO}_{3}\right)\right)\end{array}$ & & $\mathrm{X}$ & $\mathrm{X}$ & $\mathrm{X}$ & $\mathrm{X}$ & $\mathrm{X}$ & $\mathrm{X}$ & $\mathrm{X}$ & $\mathrm{X}$ & $\mathrm{X}$ & $\mathrm{X}$ & \\
\hline Sylvite $(\mathrm{KCl})$ & & $\mathrm{X}$ & & & & & & & & $\mathrm{X}$ & & \\
\hline $\begin{array}{l}\text { Arcintie } \\
\left(\mathrm{K}_{2}\left(\mathrm{SO}_{4}\right)\right)\end{array}$ & & $\mathrm{X}$ & $\mathrm{X}$ & $\mathrm{X}$ & & & $\mathrm{X}$ & $\mathrm{X}$ & & $\mathrm{X}$ & $\mathrm{X}$ & \\
\hline $\begin{array}{l}\text { Periclase } \\
(\mathrm{MgO})\end{array}$ & & $\mathrm{X}$ & & & & $\mathrm{X}$ & $\mathrm{X}$ & & & & & \\
\hline $\begin{array}{l}\text { Quick Lime } \\
(\mathrm{CaO})\end{array}$ & & & & & & $\mathrm{X}$ & $\mathrm{X}$ & & & & & \\
\hline $\begin{array}{l}\text { Wollastonite } \\
\left(\mathrm{CaSiO}_{3}\right)\end{array}$ & $\mathrm{X}$ & & & & & & & & & & & \\
\hline \multicolumn{13}{|l|}{599} \\
\hline 600 & & & & & & & & & & & & \\
\hline
\end{tabular}

601

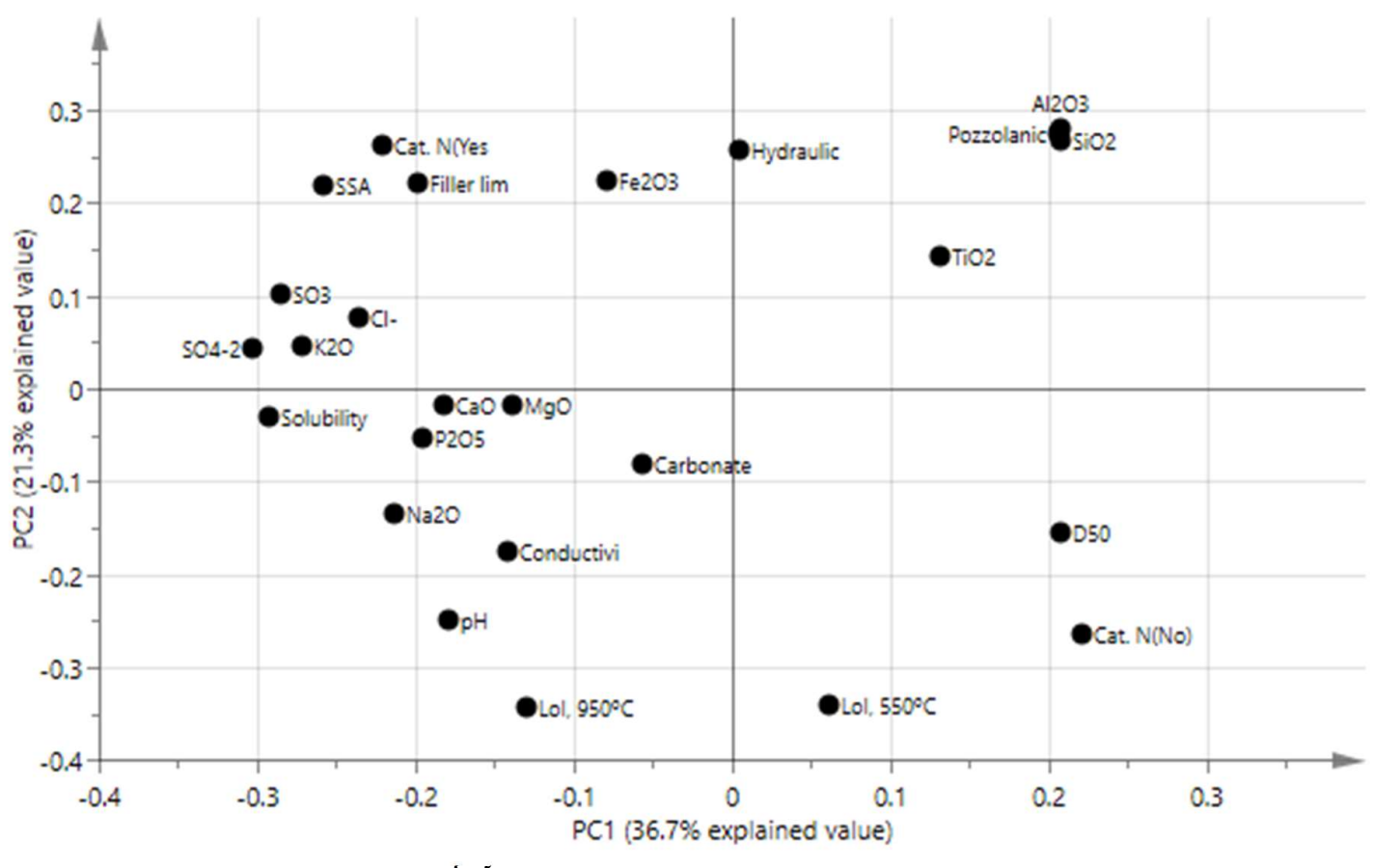

Page 22 
Table 3. Overview of relationships between the production parameters and the wood ash characteristics based on the PLS analysis. High values for the wood ash characteristics are achieved by high $(+)$ or low values $(-)$ of the given production parameter.

\begin{tabular}{|c|c|c|c|c|c|c|c|c|c|c|c|c|}
\hline & $\begin{array}{c}\text { Ash } \\
\text { type: B }\end{array}$ & $\begin{array}{l}\text { Ash type: } \\
\text { F }\end{array}$ & $\begin{array}{c}\text { Combustion } \\
\text { temperatur } \\
\text { e, middle }\end{array}$ & $\begin{array}{c}\text { Combust } \\
\text { ion } \\
\text { method: } \\
\text { CFB } \\
\end{array}$ & $\begin{array}{c}\text { Combust } \\
\text { ion } \\
\text { method: } \\
\text { Grate } \\
\end{array}$ & $\begin{array}{c}\text { Type of } \\
\text { biofuel: } \\
\text { Chips+Po } \\
\text { wder }\end{array}$ & $\begin{array}{c}\text { Ash type: } \\
\text { M }\end{array}$ & $\begin{array}{r}\text { Type of } \\
\text { biofuel: } \\
\text { Chips }\end{array}$ & $\begin{array}{c}\text { Origin of } \\
\text { biofuel: } \\
\text { Log }\end{array}$ & $\begin{array}{c}\text { Origin of } \\
\text { biofuel: Tree }\end{array}$ & $\begin{array}{c}\text { Type of } \\
\text { biofuel: } \\
\text { Pellets }\end{array}$ & $\begin{array}{c}\text { Initial } \\
\text { water } \\
\text { content, } \\
\text { middle }\end{array}$ \\
\hline $\mathrm{SiO}_{2}(\%)$ & + & & & + & - & & & + & - & + & & \\
\hline $\mathrm{Al}_{2} \mathrm{O}_{3}(\%)$ & + & & & + & - & & & & - & + & & \\
\hline $\mathrm{Fe}_{2} \mathrm{O}_{3}(\%)$ & & & & & & & - & - & - & -1 & + & - \\
\hline $\begin{array}{l}\text { E primary } \\
\text { oxides }(\%)\end{array}$ & + & & & + & - & & & + & - & + & - & \\
\hline $\mathrm{SiO}_{2} / \mathrm{CaO}(-)$ & & & & & & & & + & - & + & & \\
\hline $\mathrm{CaO}(\%)$ & - & & + & - & + & - & & & + & - & & \\
\hline $\mathrm{MgO}(\%)$ & 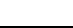 & & & & & & & - & & & + & \\
\hline $\mathrm{K}_{2} \mathrm{O}(\%)$ & - & & & 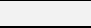 & & & & - & + & - & + & \\
\hline $\mathrm{Na}_{2} \mathrm{O}(\%)$ & - & + & + & - & 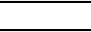 & + & & & & & & \\
\hline $\mathrm{P}_{2} \mathrm{O}_{5}(\%)$ & - & + & & - & + & & & & - & + & & \\
\hline $\mathrm{TiO}_{2}(\%)$ & & & & + & - & & & & - & + & & \\
\hline $\mathrm{SO}_{3}(\%)$ & - & + & + & & & & & & & & & \\
\hline $\mathrm{Cl}^{-}(\%)$ & - & & & & & & & + & + & - & - & \\
\hline $\mathrm{SO}_{4}^{-2}(\%)$ & - & + & + & & & & - & - & + & - & + & \\
\hline LoI, $550^{\circ} \mathrm{C}(\%)$ & & & & & & + & & & - & + & - & \\
\hline LoI, $950^{\circ} \mathrm{C}(\%)$ & - & & & - & + & + & & & - & + & & \\
\hline $\begin{array}{l}\text { Mean particle } \\
\text { size, } D_{50}(\mu \mathrm{m})\end{array}$ & + & - & - & & & + & + & + & & & - & + \\
\hline $\mathrm{SSA}\left(\mathrm{m}^{2} / \mathrm{g}\right)$ & - & + & + & & & - & - & & & & & - \\
\hline $\mathrm{pH}$ & - & & + & - & + & & & & & & & \\
\hline $\begin{array}{l}\text { Conductivity } \\
\left(\mathrm{mS} \mathrm{cm}^{-1}\right)\end{array}$ & - & + & + & & & + & & & & & & \\
\hline $\begin{array}{l}\text { Carbonate } \\
\text { content (\%) }\end{array}$ & & & & & & - & & - & + & - & + & - \\
\hline $\begin{array}{l}\text { Water solubility } \\
(\%)\end{array}$ & - & + & + & - & + & + & & - & + & - & + & \\
\hline $\begin{array}{l}\text { Category } \mathrm{N}(\mathrm{Y} \\
=+/ \mathrm{N}=-)\end{array}$ & & + & & & & & - & & & & & - \\
\hline$<250 \mu \mathrm{m}$ & & + & + & & & - & - & - & & & + & - \\
\hline
\end{tabular}

607 Table 4. VIP values of the variables in the X-matrix in descending order.

608

609

610

611

612

613

614

615

616

\begin{tabular}{lc}
\hline Variable & VIP-value \\
\hline Ash type: $\mathrm{F}$ & 1.27 \\
Combustion method: CFB & 1.16 \\
Combustion method: Grate & 1.16 \\
Ash type: B & 1.13 \\
Type of biofuel: Chips & 1.09 \\
Ash type: M & 0.98 \\
Type of biofuel: Chips+Powder & 0.95 \\
Initial water content, average & 0.95 \\
Type of biofuel: Pellets & 0.90 \\
Combustion temperature, average & 0.82 \\
Origin of biofuel: Log & 0.70 \\
Origin of biofuel: Tree & 0.70 \\
\hline
\end{tabular}


Figure 2. $\mathrm{CaO}-\mathrm{SiO}_{2}-\mathrm{Al}_{2} \mathrm{O}_{3}$ ternary diagram for the investigated wood ashes. Black triangle $\boldsymbol{\Delta}$ : bottom ash, black square $:$ mixed ash and black dot $\bullet$ : fly ash. Ternary diagram adapted from Lothenbach et al., (2011).
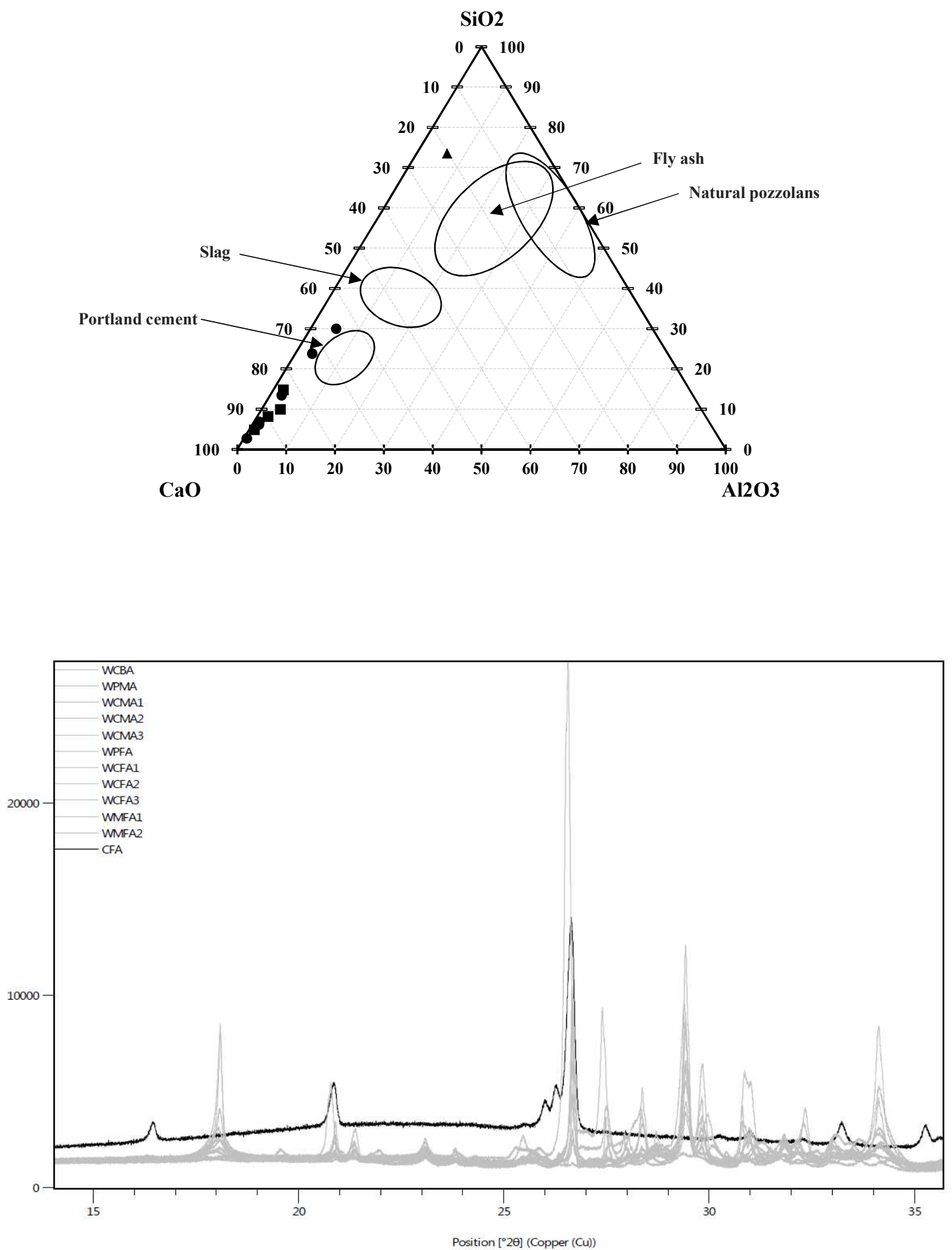

Figure 3. Comparison between the XRD diffractograms from $15^{\circ} 2 \theta$ to $35^{\circ} 2 \theta$ (amorphous rise) for the investigated 621 WA and a coal fly ash. 


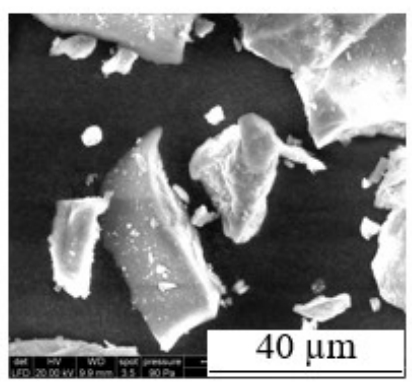

a) WCBA

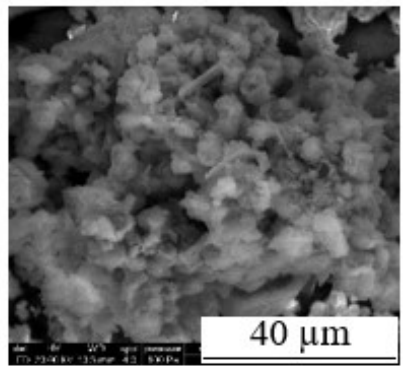

d) WCMA2

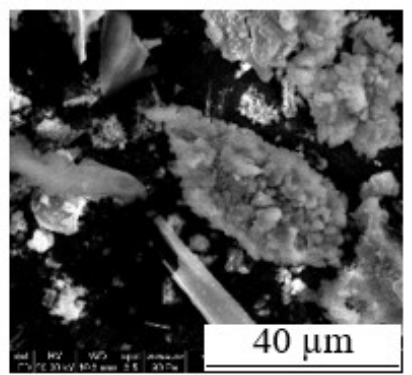

g) WCFA1

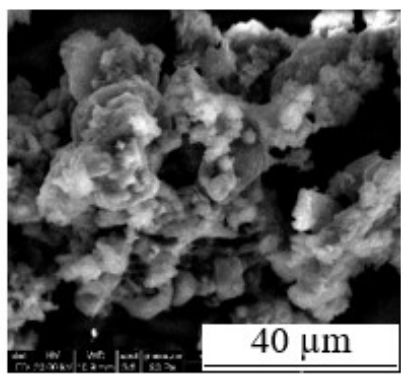

j) WMFA2

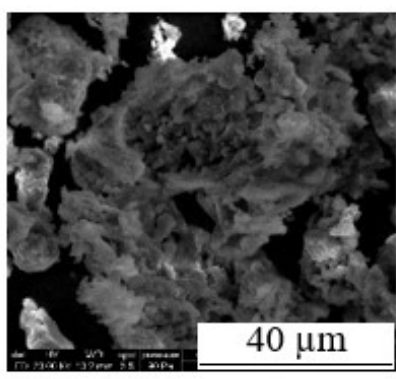

b) WPMA

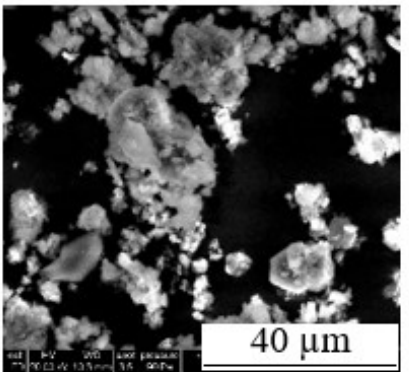

e) WCMA3

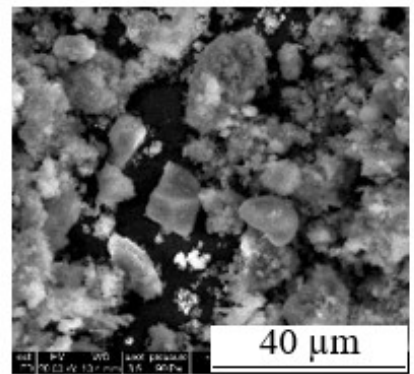

h) WCFA2

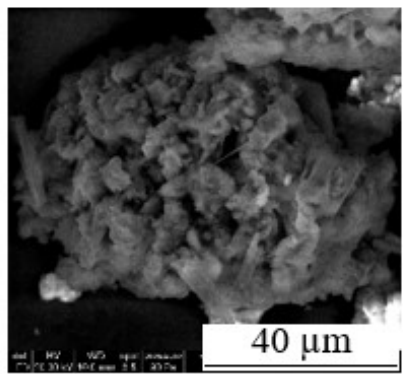

k) WMFA1

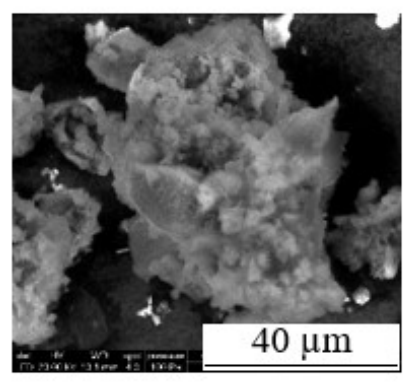

c) WCMA1

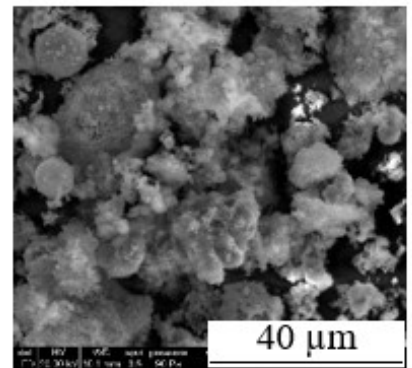

f) WPFA

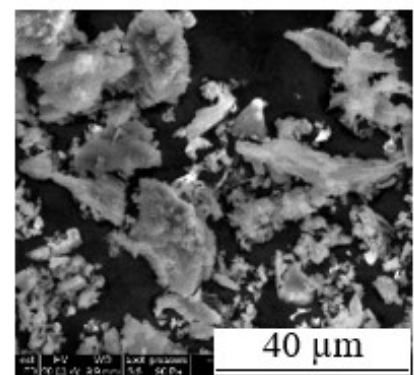

i) $\mathrm{WCFA} 3$

Figure 4. SEM images displaying the 11 investigated WA. 